\title{
Ecological Risk Assessment of Heavy Metals in Coastal Sediments between Al-Haymah and Al-Mokha, South Red Sea, Yemen
}

\author{
Majed A M Al-Edresy ${ }^{1}$, Saeed O Wasel ${ }^{2}$ and Hagib A Al-Hagibi ${ }^{3}$ \\ ${ }^{1}$ Department of Marine Chemistry and Pollution, Hodeidah University, Yemen \\ ${ }^{2}$ Department of Marine Geology, Hodeidah University, Yemen \\ ${ }^{3}$ Department Earth and Environmental Sciences, Sana'a University, Yemen
}

Submission: April 04, 2019; Published: May 31, 2019

*Corresponding author: Hagib A. Al-Hagibi, Department Earth and Environmental Sciences, Sana'a University, Yemen

\begin{abstract}
The area between Al-Haymah and Al-Mokha on the Red Sea of Yemen is a promising region for future tourism development. It is also characterized by population activities, especially fishing in more than one location and there is a commercial port in Al-Mokha. The aim of the present study is to investigate the distribution of heavy metals $(\mathrm{Cu}, \mathrm{Cd}, \mathrm{Zn}, \mathrm{Ni}$ and $\mathrm{Pb}$ ) and Ecological Risk Assessment to assess the contamination levels of the coastal surface sediments. Distribution and ecological risk for $\mathrm{Cu}, \mathrm{Cd}, \mathrm{Zn}, \mathrm{Ni}$ and $\mathrm{Pb}$ in sediment samples collected from 11 regions (37 stations) in the coasts of Yemen were studied. The results showed that the most of sediments are sand (83.83\%), the content of organic matter was low (1.4\%) and rich of calcium carbonate (56.1\%) while the heavy metals arranged according to their abundance as follows: $\mathrm{Zn}>$ $\mathrm{Cu}>\mathrm{Ni}>\mathrm{Pb}>\mathrm{Cd}$. The contamination factor values for heavy metals arranged according to their dangerous as follows: $\mathrm{Cd}>\mathrm{Cu}>\mathrm{Zn}>\mathrm{Pb}>\mathrm{Ni}$, and the potential ecological risk index values for heavy metals, according to the order evaluation of pollution in the various regions as follows: (Qataba $>$ Al-Mokha $>$ North Al-Mokha $>$ Al-Ruays $>$ Abu-Zahr $>$ South Al-Mokha $>$ Zahari $>$ Al-Khowkhah $>$ Al-Haymah $>$ Yokhtul $>$ Moushij). The present study shows that the coastal sediments in this part of the Red Sea coast of Yemen are not Polluted by heavy metals $\mathrm{Cu}, \mathrm{Zn}, \mathrm{Ni}$ and $\mathrm{Pb}$, but it heavily polluted by $\mathrm{Cd}$.
\end{abstract}

Keywords: Red sea; Coastal sediment; Heavy metal pollution; Contamination factor; Potential ecological risk index

\section{Introduction}

The sediments are usually the ultimate sink of heavy metals discharged into the aquatic environments, therefore, analysis of heavy metals (and other contaminants) in the sediments offers a more convenient and more accurate means of detecting and assessing the degree of pollution [1,2]. Sediments serve as the ultimate sink for many contaminants and as a result, they pose the highest risk to the aquatic life as a source of pollution [3]. The sediments are the main repository and source of heavy metals in the marine environment and that they play a major role in the transport and storage of potentially hazardous metals [4]. In addition, heavy metal concentrations in surface sediments can provide historical information on heavy metal inputs at that location, where surface sediments used as environmental indicators to reflect the current quality of marine systems for many pollutants [5]. Sediment acts as a sink for metals and the highest concentrations of toxic heavy metals in marine environment are found in sediments $[1,6,7]$.

Coastal sediments are important hosts for heavy metal pollution and play an important role in determining the fate and effects of a wide variety of contaminants [8]. Vertical concentration gradients of heavy metals in sediment cores can provide temporal information about the perturbation in the aquatic environment [9]. The distribution of metals in sediment is very important from the point of view of environmental pollution because sediment concentrates metals from aquatic systems and represents an appropriate medium to monitor contamination due to sediments are the principal sinks for heavy metals in an aquatic system $[1,7,10]$.

Although metals occur in the ecosystem naturally by geogenic and lithogenic processes, the heavy metals of anthropogenic 


\section{Ecology \& Conservation Science: Open Access}

origin tend to be bioavailable and then toxic pollutants [11]. Nijenhuis [12] reported that the enrichment of trace elements in marine sediments may, in general, originate from the following sources; super-and subjacent sediments, through diagenesis; suboxic shelf and slope sediments, hydrothermal input; Aeolian input; fluvial runoff; seawater. Under natural condition, the most important inputs of heavy metals to coastal regions are the mechanical weathering of rooks [13]. Urban and industrial activities contribute to the introduction of significant amounts of pollutants (among them trace metals) into the marine environment and affect directly the coastal systems where they are quite often deposited $[1,7,14]$.

In some places along the Red Sea coast of Yemen heavy minerals are usually common and represent $50 \%$ or more of the beach deposits [15]. These beach deposits are mainly derived from mountainous regions, which drain from the Yemen highlands to the sea through numerous valleys [7,16-18]. The Red Sea environments receive either locally or more widely, a variety of stresses as a result of human activities. The different anthropogenic activities included recreational resorts, urban agglomeration, marine shipping, activities of phosphate industry and fishing ports, as well as limited freshwater and sewage sources [2,19].

The present study was conducted in order to monitor, investigate and Ecological Risk Assessment the accumulation of heavy metals $(\mathrm{Cu}, \mathrm{Cd}, \mathrm{Zn}, \mathrm{Ni}$ and $\mathrm{Pb})$ in coastal sediments in the intertidal zones between $\mathrm{Al}-\mathrm{Haymah}$ and $\mathrm{Al}-\mathrm{Mokha}$ of south Red Sea Coast Yemen.

\section{Material and method}

The methods section includes study areas, sample collection and lab analysis, assessment of potential ecological risk and statistical analysis.

\section{Study area}

The study area extends from Al-Haymah to south Al-Mokha along Red Sea and covering a distance of about $90 \mathrm{Km}$ along the Shore line, and, lies between Longitude $43^{\circ} 13^{\prime}$ and $43^{\circ} 30^{\prime} \mathrm{E}$ and Latitude $13^{\circ} 15^{\prime}$ and $13^{\circ} 55^{\prime} \mathrm{N}$ and comprises the areas of Al-Haymah, Qataba, Abu-Zahr, Al-Khowkhah, Moushij, Al-Zahari, Al-Ruays, Yokhtol and Al-Mokha (Figure 1).

\section{Sampling and analytical procedure}

Thirty-seven surface sediments were collected from beach area Figure 1. The samples were dried in an oven at about $60 \mathrm{oC}$; then each sample placed on white glassed paper and crushed with fingers and was separated into two parts, one for grain size distribution by dry sieving and pipit analysis. The second portion was used for chemical analysis. Ten grams of each prepared subsamples of selected samples were ground using agate mortar, passed through $3 \varnothing$ sieve and kept in dry clean bag waiting for chemical analysis and it comprised, total Carbonates, organic matter and total elements. 
$T_{i}$ is the toxic response factor for a given substance, which accounts for the toxic and sensitivity requirement, and the values for $\mathrm{Cd}, \mathrm{Cu}, \mathrm{Pb}, \mathrm{Ni}, \mathrm{Zn}$ and $\mathrm{Cr}$ are 30, 5, 5, 5, 1 and 2, respectively $[25,26]$.

CFi is the contamination factor.

\section{Potential ecological risk index (RI):}

Håkanson [23] developed a methodology to assess ecological risks for aquatic pollution control. The methodology assumes that the sensitivity of the aquatic system depends on its productivity. The potential ecological risk index (RI) was introduced to assess the degree of heavy metal pollution in sediments, according to the toxicity of heavy metals and the response of the environment:

$$
R I=\Sigma E_{i}^{n}
$$

Where, RI is calculated as the sum of all risk factors for heavy metals in sediments

\section{Statistical analysis}

Multivariate statistics have been frequently applied to quantify the contribution of environmental factors to sediment quality parameters [16]. In this study, correlation coefficients were calculated to reveal the relationships between sediments and heavy metals. Data were processed with Win RAR statistical software.

\section{Results and Discussion}

In Table 1 the relative distribution of the grain size analysis (gravel, sand and clay), and the percentage distribution of organic substances and calcium carbonate sediments in the south of Yemen's Red Sea coast (Al-Haymah - Al-Mokha).

Table 1: Classes of Contamination Factor (CF), Degree Contamination (DC), Pollution Load Index (PLI), Potential Ecological Risk (Ei), and Potential Ecological Risk Index (RI).

\begin{tabular}{|c|c|c|c|}
\hline & Value & Sediment Quality & Reference \\
\hline \multirow{4}{*}{$\mathrm{CF}$} & $\mathrm{CF}<1$ & Low Contamination. & Savvides et al [24]; Pekey et al. [50] \\
\hline & $1 \leq \mathrm{CF}<3$ & Moderate Contamination & \\
\hline & $3 \leq \mathrm{CF}<6$ & Considerable Contamination & \\
\hline & $\mathrm{CF} \geq 6$ & Very high Contamination & \\
\hline \multirow{5}{*}{$\mathrm{E}_{\mathrm{i}}$} & $\mathrm{Ei}<30$ & Low Risk & Gan et al. [49]s \\
\hline & $30 \leq \mathrm{Ei}<50$ & Moderate Risk & \\
\hline & $50 \leq \mathrm{Ei}<100$ & Considerable Risk & \\
\hline & $100 \leq \mathrm{Ei}<150$ & Very High Risk & \\
\hline & $\mathrm{Ei} \geq 150$ & Disastrous Risk & \\
\hline \multirow{5}{*}{ RI } & $\mathrm{RI}<100$ & Low Risk & \\
\hline & $100 \leq \mathrm{RI}<150$ & Moderate Risk & \\
\hline & $150 \leq \mathrm{RI}<200$ & Considerable Risk & \\
\hline & $200 \leq \mathrm{RI}<300$ & Very High Risk & \\
\hline & $\mathrm{RI} \geq 300$ & Disastrous Risk & \\
\hline
\end{tabular}

\section{Grain size}

Grain size is one of the most important factors controlling sediment capacity for concentrating and retaining metals $[1,7]$. It is well known that elements are not homogeneously distributed over the various grain size fractions [27]. There is a strong relation between an increase in metal concentration and a decrease in grain size. Fine-grained particles, because of their large specific surface areas, are the main sites for the accumulation and transport of metals [28]. Since fine grain are more soluble than coarser ones the bioavailability of metals increase with decreasing the grains that metals are fixed with [28].
The results of the granulometric analysis of the surface sediment samples of the south of Yemen's Red Sea coast (AlHaymah - Al-Mokha) are listed in Table 2. The gravel fraction of the sediment ranged between $0.0 \%$ at stations $(8,9,10$ and 24) in Al-Khowkhah, Al-Ruays and North Al-Mokha regions and $56.16 \%$ at station (2) in Al-Haymah region with the overall average of $(8.93 \%)$, the sand fraction of the sediment ranged between $43.84 \%$ at station (2) in Al-Haymah region and $99.93 \%$ at stations (8 and 31) in Al-Khowkhah and North Al-Mokha regions with the overall average of (83.82\%) and Mud fraction of the sediment ranged between $0.0 \%$ at station (2) in Al-Haymah region and $45.36 \%$ at station (23) in Al-Rusys region with the overall average of $(6.38 \%)$. 
Table 2: The relative distribution of the grain size analysis, and the percentage distribution of organic matter (OM) and calcium carbonate $\left(\mathrm{CaCO}_{3}\right)$ in sediments at the south of Yemen's Red Sea coast (Al-Haymah - Al-Mokha).

\begin{tabular}{|c|c|c|c|c|c|c|}
\hline \multirow{2}{*}{ Regions } & \multirow{2}{*}{ Sts. No } & \multicolumn{3}{|c|}{ Grain Size\% } & \multirow{2}{*}{ ОМ\% } & \multirow{2}{*}{$\mathrm{CaCo}_{3} \%$} \\
\hline & & Gravel & Sand & Mud & & \\
\hline \multirow{3}{*}{ Al-Haymah } & 1 & 1.5 & 98.33 & 0.17 & 1.11 & 37.26 \\
\hline & 2 & 56.16 & 43.84 & 0 & 1.17 & 38.76 \\
\hline & Average & 28.83 & 71.09 & 0.09 & 1.14 & 38.01 \\
\hline Qataba & 3 & 27.5 & 72.45 & 0.05 & 0.91 & 56.38 \\
\hline \multirow{5}{*}{ Abu-Zahr } & 4 & 26.56 & 67.49 & 5.95 & 1.95 & 27.17 \\
\hline & 5 & 13.21 & 86.7 & 0.09 & 0.98 & 45.22 \\
\hline & 6 & 1.1 & 98.73 & 0.17 & 1.16 & 57.58 \\
\hline & 7 & 7.88 & 86.2 & 5.92 & 1.12 & 39.56 \\
\hline & Average & 12.19 & 84.78 & 3.03 & 1.3 & 42.38 \\
\hline \multirow{8}{*}{ Al-Khowkhah } & 8 & 0 & 99.93 & 0.07 & 2.72 & 62.92 \\
\hline & 9 & 0 & 91.01 & 8.99 & 0.71 & 32.78 \\
\hline & 10 & 0 & 67.43 & 32.57 & 0.59 & 35.58 \\
\hline & 11 & 2.42 & 96.88 & 0.7 & 0.57 & 45.34 \\
\hline & 12 & 2.42 & 96.88 & 0.7 & 0.7 & 52.66 \\
\hline & 13 & - & - & - & - & - \\
\hline & 14 & 1.07 & 98.67 & 0.26 & 1.13 & 57.82 \\
\hline & Average & 0.99 & 91.8 & 7.22 & 1.07 & 47.85 \\
\hline \multirow{3}{*}{ Mawshij } & 15 & 0.24 & 99.6 & 0.16 & 0.65 & 45.22 \\
\hline & 16 & 39.99 & 57.98 & 2.03 & 0.85 & 40.54 \\
\hline & Average & 20.12 & 78.79 & 1.1 & 0.75 & 42.88 \\
\hline \multirow{5}{*}{ Zahari } & 17 & 1.11 & 98.29 & 0.6 & 0.48 & 48.3 \\
\hline & 18 & 0.23 & 95.89 & 3.88 & 1.3 & 62.4 \\
\hline & 19 & 0.05 & 78.85 & 21.1 & 4.58 & 67.23 \\
\hline & 20 & 0.25 & 77.82 & 21.94 & 4.16 & 69.6 \\
\hline & Average & 0.41 & 87.71 & 11.88 & 2.63 & 61.88 \\
\hline \multirow{5}{*}{ Al-Ruays } & 21 & 8.62 & 75.71 & 15.67 & 1.29 & 88.64 \\
\hline & 22 & 9.76 & 90.21 & 0.03 & 0.78 & 95.41 \\
\hline & 23 & 2.92 & 51.72 & 45.36 & 4.47 & 71.68 \\
\hline & 24 & 0 & 62.29 & 37,71 & 1.09 & 38.2 \\
\hline & Average & 5.33 & 69.89 & 20.35 & 1.91 & 73.48 \\
\hline \multirow{6}{*}{ Yakhtul } & 25 & 7.91 & 90.34 & 1.75 & 0.75 & 84.96 \\
\hline & 26 & 22.46 & 74.22 & 3.32 & 1.58 & 91.81 \\
\hline & 27 & 0.14 & 91.18 & 8.68 & 0.72 & 58.66 \\
\hline & 28 & 0.81 & 92.85 & 6.34 & 1.21 & 52.26 \\
\hline & 29 & 0.43 & 66.13 & 33.44 & 2.56 & 61.88 \\
\hline & Average & 6.35 & 82.94 & 10.71 & 1.36 & 69.91 \\
\hline \multirow{5}{*}{ North Al-MoKha } & 30 & 1.81 & 95.24 & 2.95 & 0.57 & 65.68 \\
\hline & 31 & 0 & 99.93 & 0.07 & 0.57 & 40.54 \\
\hline & 32 & 1.19 & 98.76 & 0.05 & 0.66 & 53.22 \\
\hline & 33 & 10.4 & 89.59 & 0.01 & 1.06 & 55.78 \\
\hline & Average & 3.35 & 95.88 & 0.77 & 0.72 & 53.81 \\
\hline \multirow{3}{*}{ Al-Mokha } & 34 & 17.34 & 82.62 & 0.04 & 1.95 & 52.06 \\
\hline & 35 & 7.55 & 92.32 & 0.13 & 2.14 & 58.52 \\
\hline & Average & 12.45 & 87.47 & 0.09 & 2.05 & 55.29 \\
\hline
\end{tabular}




\section{Ecology \& Conservation Science: Open Access}

\begin{tabular}{|c|c|c|c|c|c|c|}
\hline \multirow{3}{*}{ South Al-Mokha } & 36 & 24.08 & 75.74 & 0.18 & 1.1 & 53.84 \\
\cline { 2 - 7 } & 37 & 24.29 & 75.65 & 0.06 & 1.18 & 74.2 \\
\cline { 2 - 7 } & Average & 24.19 & 75.7 & 0.12 & 1.14 & 64.02 \\
\hline Min & $(36)$ & 0 & 43.84 & 0 & 4.58 & 95.41 \\
\hline Max & & 56.16 & 99.93 & 45.36 & 1.4 & 56.1 \\
\hline Area Average & & 8.93 & 83.82 & 6.38 & & \\
\hline
\end{tabular}

The mud fraction in the sediment samples represented less than $10 \%$ of total sediment except those at stations $(10,19,20$, $21,23,24$ and 29) where this fraction reached values higher than $10 \%$. Station 23 its mud content was $45.36 \%$. This means that the sediments in the present study area are mainly sandy. In each of the regions study the mud content of the sediments less than $10 \%$ at average except of three regions Al-Ruays, Zahari and Yakhtul $(20.35 \%, 11.88 \%$ and 10.71$)$ respectively.

\section{Organic matter (OM)}

Organic matter plays the key role as a heavy metal carrier $[7,11]$. Dissolved organic matter can influences on the distribution of metals as follows: Dissolved organic substances are capable of

1. complexing metals and increasing metal solubility

2. altering the distribution between oxidized and reduced forms of metals

3. alleviating metals toxicity and altering metal availability to aquatic life

4. influencing the extent to which metals are adsorbed on suspended matter

5. affecting the stability of metal-containing colloids $[1,11]$.

Heavy metals in sediment usually are affected by TOM content $[1,7,17,29]$. On the other hand the trace metal variability in the sediments has been found to be related to grain size, mineralogy, and organic carbon [7].The results of the percentage organic matter (OM) of the surface sediment samples of the south of Yemen's Red Sea coast (Al-Haymah - Al-Mokha) are listed in Table 2. The percentage distribution of organic matter of the sediment ranged between $0.48 \%$ at station (17) in Zahari region and $4.58 \%$ at station (19) Zahari region also with the overall average of $(1.4 \%)$. The organic matter in the sediment samples represented less than $2 \%$ of total sediment except those at stations $(8,19,20,23,29$ and 35) where this fraction reached values higher than $2 \%$. Station 19 and 20 at Zahari its organic matter content was $4.58 \%$ and $4.16 \%$ also station (23) at AlRuays its organic matter content was $4.47 \%$.

The high organic matter content in Zahari and AL-Ruays area is attributed to the high seagrasses cover in the tidal flat zone. The OM\% in the present study areas is lower than those of reported by Sagheer [16] in North of Al-Hudaydah and Al-Luhayyah Red Sea coast of Yemen, reflecting that their sediments were mostly closer to the coastline and its much lower than those reported by Basaham (1998) in the polluted Al-Arbaeen Lagoon [6], in Red Sea coast of Jeddah. The OM\% in the present study areas is larger than those of Al-Edresy [1], Al-Hagibi [7], Heba et al. [16].

\section{Calcium carbonate $\left(\mathrm{CaCo}_{3}\right)$}

The results of the calcium carbonate $\left(\mathrm{CaCo}_{3} \%\right)$ of the surface sediment samples of the south of Yemen's Red Sea coast (Al-Haymah - Al-Mokha) are listed in Table 2. The percentage distribution of $\mathrm{CaCo}_{3}$ of the sediment ranged between $27.17 \%$ at station (4) in Abu-Zahar region and $95.41 \%$ at station (22) Al-Ruays region with the overall average of (56.1\%). The calcium carbonate content was very high at Al-Ruays region with average value of $73.48 \%$, in general the $\mathrm{CaCo}_{3} \%$ in the present study was high in all regions. The high values of calcium carbonate content can be attributed to the accumulation of large amounts of shell fragments blanketing the bottom sediment [30].

The $\mathrm{CaCo}_{3} \%$ in the current study areas is larger than those of Sagheer [31] \& Al-Edresy [1] \& the $\mathrm{CaCo}_{3} \%$ in present study SE-Red Sea remarkably is slightly higher than that found by Mahmoud [32] in the NW Hurgada Red Sea coast, Egypt.

\section{Heavy metals}

Heavy metal concentrations in coastal environment have been rapidly increased by human activities because the coastal environments are subjected to metal contamination throughout various inputs such as natural, industrial and urban sources. Metals released into coastal environments rapidly bind to particulate and sink to the sediments; thus, metals accumulate in sediments. However, sediments in coastal environment are a sink as well as possible delayed source for heavy metals into the aquatic phase due to desorption and remobilization with changing physiochemical conditions [33].

Most suspended particles in seawater have a strong affinity for binding to metals, and metals in the formation of complexes with suspended particles are subsequently precipitated into bottom sediments, causing metal accumulation in sediments [34]. Sediments can become a source of metals, releasing them into the overlying water column [1]. Monitoring of metal levels in sediments are useful indicators of anthropogenic inputs to evaluate metal contamination and to predict influence on marine ecosystem. However, in the study area has no industrial activity. There are some human activities such as fisheries, which are in all regions of study and different levels regarded as Al-Khowkhah and Al-Mokha of the largest fisheries in the study 
area and there is also a commercial port city of Al-Mokha. AlMokha larger study areas and most active population followed Al-Khowkhah region.

Distribution of Heavy metals $(\mathrm{Cu}, \mathrm{Cd}, \mathrm{Zn}, \mathrm{Ni}$ and $\mathrm{Pb})$ in the study area, average in regions and the general average of the study area are illustrated in Table 3 , and the percentage of the spatial distribution of heavy metal $(\mathrm{Cu}, \mathrm{Cd}, \mathrm{Zn}, \mathrm{Ni}$ and $\mathrm{Pb})$ in every region of the study areas are illustrated in Figure 2. Table 1 showed that all the metals that have been studied record values were lower than the Background values (Shale), Except cadmium record high in value in most stations, Copper record high values in four stations $(8,21,34$ and 37) in Al-Khowkhah, Al-Ruays, AlMokha and South Al-Mokha respectively and Lead record high values in three stations $(10,14)$ in $\mathrm{Al}$-Khowkhah region and station (27) in Yakhtul. The heavy metals in the sediments of the present study areas arranged according to their abundance as follows: $\mathrm{Zn}>\mathrm{Cu}>\mathrm{Ni}>\mathrm{Pb}>\mathrm{Cd}$.

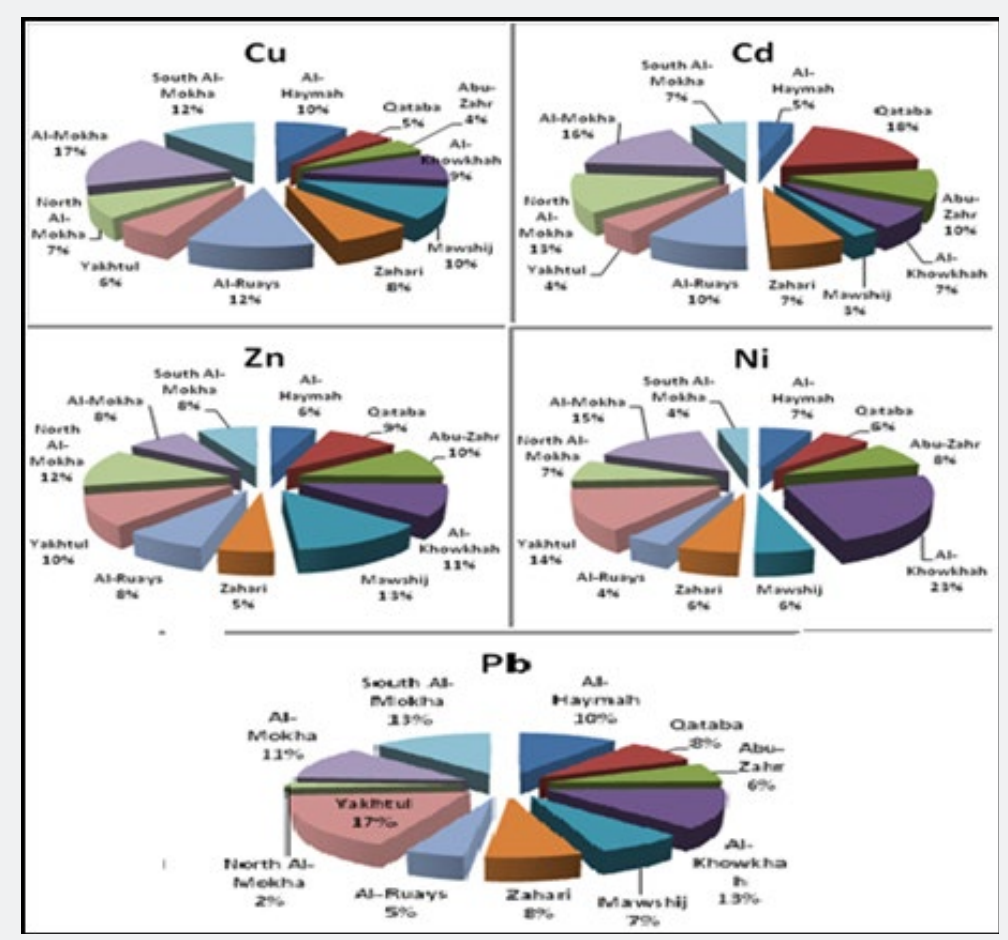

Figure 2: The percentage distribution of Heavy Metals in Coastal Sediments from the south of Yemen's Red Sea coast (Al-Haymah - AlMokha).

Table 3: Concentration of heavy metals $(\mu \mathrm{g} / \mathrm{g})$ in Coastal Sediments between Al-Haymah and Al-Mokha, South Red Sea, Yemen.

\begin{tabular}{|c|c|c|c|c|c|c|}
\hline Regions & Stations No & $\mathrm{Cu}$ & Cd & Zn & $\mathbf{N i}$ & $\mathbf{P b}$ \\
\hline \multirow{3}{*}{ Al-Haymah } & 1 & 10.3 & 0.5 & 36 & 11.17 & 1.6 \\
\hline & 2 & 27.93 & 0.33 & 10.82 & 0.33 & 13 \\
\hline & Average & 19.12 & 0.42 & 23.41 & 5.75 & 7.3 \\
\hline Qataba & 3 & 9.31 & 1.67 & 36.8 & 5.33 & 5.33 \\
\hline \multirow{5}{*}{ Abu-Zahr } & 4 & 9.31 & 0.67 & 30.3 & 0.33 & 0.33 \\
\hline & 5 & 7.3 & 1 & 34.8 & 14.3 & 3 \\
\hline & 6 & 9.5 & 0.83 & 35.7 & 8.17 & 9.5 \\
\hline & 7 & 9.31 & 1 & 56.28 & 4 & 4.33 \\
\hline & Average & 8.86 & 0.94 & 39.27 & 6.7 & 4.29 \\
\hline \multirow{6}{*}{ Al-Khowkhah } & 8 & 55.78 & 0.33 & 34.63 & 1 & 2 \\
\hline & 9 & 15.3 & 1.33 & 64.3 & 18.83 & 3.7 \\
\hline & 10 & 18.7 & 1.5 & 46 & 39.33 & 23.3 \\
\hline & 11 & 3.3 & 0.17 & 46.3 & 38.5 & 2.33 \\
\hline & 12 & 9.3 & 0.33 & 47.62 & 2.67 & 1.67 \\
\hline & 13 & 18.62 & ND & 21.65 & 5.33 & 2.27 \\
\hline
\end{tabular}


Ecology \& Conservation Science: Open Access

\begin{tabular}{|c|c|c|c|c|c|c|}
\hline & 14 & 3.3 & 0.65 & 27.6 & 29.17 & 26.5 \\
\hline & Average & 17.76 & 0.62 & 41.16 & 19.26 & 8.82 \\
\hline \multirow{3}{*}{ Mawshij } & 15 & 27.82 & 0.17 & 49.78 & 5.33 & 5 \\
\hline & 16 & 13 & 0.33 & 52.6 & 4.32 & 4.62 \\
\hline & Average & 20.41 & 0.25 & 51.19 & 4.83 & 4.81 \\
\hline \multirow{5}{*}{ Zahari } & 17 & 18.62 & 0.67 & 23.81 & 0.33 & 3 \\
\hline & 18 & 9.31 & 1 & 2.61 & 1 & 2.67 \\
\hline & 19 & 27.95 & 0.33 & 43.29 & 2.33 & 2.33 \\
\hline & 20 & 5 & 0.66 & 16 & 15.83 & 13.03 \\
\hline & Average & 15.22 & 0.67 & 21.43 & 4.87 & 5.26 \\
\hline \multirow{5}{*}{ Al-Ruays } & 21 & 55.77 & 0.5 & 43.29 & 2.33 & 3.67 \\
\hline & 22 & 6 & 0.5 & 20.7 & 6.67 & 2.67 \\
\hline & 23 & 34.6 & 1.67 & 32,50 & 4.67 & 6.35 \\
\hline & 24 & 2.67 & 1.01 & 26.3 & ND & 0.15 \\
\hline & Average & 24.76 & 0.92 & 30.1 & 3.42 & 3.21 \\
\hline \multirow{6}{*}{ Yakhtul } & 25 & 1.6 & 0.83 & 15 & 12 & 1 \\
\hline & 26 & 28.39 & ND & 58.44 & 2.67 & 2.67 \\
\hline & 27 & 11 & 0.5 & 52.6 & 12.83 & 30.31 \\
\hline & 28 & 12 & 0.32 & 45.8 & 7.34 & 14.72 \\
\hline & 29 & 3.3 & 0.33 & 27.2 & 21.67 & 10.38 \\
\hline & Average & 11.26 & 0.4 & 39.81 & 11.3 & 11.82 \\
\hline \multirow{5}{*}{ North Al-Mokha } & 30 & 9.3 & 0.17 & 32.6 & 1.96 & 1.33 \\
\hline & 31 & 1.7 & 0.83 & 26.7 & 16.67 & 1.67 \\
\hline & 32 & 9.31 & 1.67 & 90.91 & 2.67 & 0.67 \\
\hline & 33 & 37.24 & 2 & 45.45 & 2 & 1.33 \\
\hline & Average & 14.39 & 1.17 & 48.92 & 5.83 & 1.25 \\
\hline \multirow{3}{*}{ Al-Mokha } & 34 & 65.18 & 1 & 34.63 & 0.67 & 1.67 \\
\hline & 35 & 4.7 & 1.97 & 27.3 & 24 & 13.84 \\
\hline & Average & 34.94 & 1.49 & 30.97 & 12.34 & 7.76 \\
\hline \multirow{3}{*}{ South Al-Mokha } & 36 & 2.3 & 0.68 & 24.6 & 6.67 & 15.3 \\
\hline & 37 & 47.54 & 0.67 & 36.8 & ND & 2.33 \\
\hline & Average & 24.92 & 0.68 & 30.7 & 3.34 & 8.82 \\
\hline Min & -37 & 1.6 & ND & 2.61 & ND & 0.15 \\
\hline Max & & 65.18 & 2 & 90.91 & 39.33 & 30.31 \\
\hline Area Average & & 17.34 & 0.76 & 36.81 & 8.98 & 6.47 \\
\hline Background in Shale & 45 & 0.3 & 95 & 68 & 20 & \\
\hline
\end{tabular}

\section{Copper (Cu):}

Copper is widely distributed in nature in the free state and in sulfides, arsenide, chlorides and carbonates [35]. The natural input of $\mathrm{Cu}$ to the marine environment from erosion of mineralized rocks on earth is estimated to be 325,000t/y. Inputs of $\mathrm{Cu}$ due to human activities are usually localized and very widely exceeded 75 milliont/y. These are often produced for use in electrical equipment, in alloys, as a chemical catalyst, in antifouling paint for ships hulls as an algaecide and as a wood preservative. Several of these uses inevitably result in $\mathrm{Cu}$ being transferred to the environment [36]. Copper is an essential trace element required by most aquatic organisms, but its high concentration is toxic [37].

Of the Table 3, concentrations ranged from copper in the sediments of the study areas between $1.6 \mu \mathrm{g} / \mathrm{g}$ sediments in the station (21), in an area disturbed and $65.18 \mu \mathrm{g} / \mathrm{g}$ in the station (34), in each of Mokha, with the overall average of $17.34 \mu \mathrm{g} / \mathrm{g}$. The maximum value of $(65.18 \mu \mathrm{g} / \mathrm{g})$ of copper. This could be due to various commercial activities, especially in the port of Mokha including corrosive paints anti-fouling of ships. These 


\section{Ecology \& Conservation Science: Open Access}

concentrations of copper higher than the concentrations of copper and has been in the creek and all its port Hodidah $2.1 \mu \mathrm{g} / \mathrm{g}$, the average whole area of $1.7 \mu \mathrm{g} / \mathrm{g}$, recorded by Al-Edresy [1].

The present values of $\mathrm{Cu}$ in the sediments are higher than in those reported by each of Heba \& Al-Mudaffer [38]; Al-Edresy [39] and Heba et al. [16]. The percentage distribution of copper contents Figure 2 showed that the $\mathrm{Cu}$ contents are arranged according to their abundance as follows: Al-Mokha > South Mokha; Al-Ruays > Al-Haymah; Moushij > Al-Khowkhah > Zahari $>$ North Mokha $>$ Yokhtul $>$ Qataba $>$ Abu-Zahr. The high copper content in the samples collected from the area and Al-Mokha and South Mokha; Al-Ruays can be attributed to the maintenance of fishing and tourist boats in the fishing port and commercial activity of the port of Mokha.

\section{Cadmium (Cd)}

Cadmium is most commonly found associated with $\mathrm{Zn}$ in carbonate and sulfides ores. $\mathrm{Cd}$ is also produced as a by-product in the refining of other metals. Thus, human through their production of metals like $\mathrm{Cu}, \mathrm{Pb}$ and $\mathrm{Zn}$ for several centuries were unknowingly polluting the environment with $\mathrm{Cd}$. Cadmium is highly toxic and originates from anthropogenic activities. It was found that more than $90 \%$ of cadmium in marine environments is of anthropogenic origin [40].

From the Table 3 , in the sediments of the present study areas the concentrations of Cd ranged between ND in the sediments of stations (13 and 26) at Al-Khowkhah and Yakhtul regions, and $2.0 \mu \mathrm{g} / \mathrm{g}$ of station (33) near the Al-Mokha Harbor in North AlMokha region, with general average $(0.76 \mu \mathrm{g} / \mathrm{g})$. Record cadmium high values in most study stations (37 stations) comparing with background value (shale) except for stations 11, 13, 15, 26 and 30. Perhaps these high concentrations of cadmium as a result of the wide spread of cadmium and very many in the industry uses. These values are higher than the values recorded by AlEdresy [1] in the port of Al-Hodeidah. The present values of $\mathrm{Cd}$ in the sediments are higher than in those reported by each of Heba \& Al-Mudaffer [38], Al-Edresy [39] \& Heba et al. [16]. The percentage distribution of cadmium contents Figure 2 showed that the Cd contents are arranged according to their abundance as follows: Qataba > Al-Mokha > North Mokha > Abu-Zahr; AlRuays > Al-Khowkhah; Zahari; South Mokha > Al-Haymah > Yokhtul > Moushij.

\section{Zinc (Zn)}

Zinc occurs in number of minerals $\mathrm{Zn}$ blends $\left(\mathrm{ZnS}, \mathrm{ZnCO}_{3}\right.$, $\mathrm{Zn}_{2} \mathrm{SiO}_{2}$ and $\mathrm{ZnO}$ ) and others. Zinc is used extensively in industry; the largest use of $\mathrm{Zn}$ is in galvanizing $\mathrm{Fe}$ and steel products. Brass is employed in a variety of applications from decorative hardware to plumbing and heat exchange units. Rolled $\mathrm{Zn}$ is required for battery production, photo engraving, lithographic printing plates, roofing, zinc oxide is also required for prints and other end-products such as photocopy paper, agricultural products, cosmetic and medical products. Zinc dust is used in the printing and dyeing of textiles, purifying fats and precipitating silver and gold from cyanide solutions [35].

From the Table 3, in the sediments of the present study areas the concentrations of $\mathrm{Zn}$ ranged between $2.61 \mu \mathrm{g} / \mathrm{g}$ in the sediments of station (18) at Zahari region, and $90.91 \mu \mathrm{g} / \mathrm{g}$ of station (32) near the Al-Mokha Harbor in North Al-Mokha region, with general average $(36.81 \mu \mathrm{g} / \mathrm{g})$. These values are higher than the values recorded by Al-Edresy [1] in the port of Al-Hodeidah. The present values of $\mathrm{Zn}$ in the sediments are higher than in those reported by each of Heba [16] \& Heba and Al-Mudaffer [38].

The increase in $\mathrm{Zn}$ content occur in beach sediments of the studied areas is due to the influence of terrigenous fragments rich in this element and principally derived from volcanic rocks. From the Figure 2 the percentage distribution of zinc contents in the sediments of the present study areas showed that the contents are arranged according to their abundance as follows: Moushij > North Mokha > Al-Khowkhah > Abu-Zahr; Yokhtul $>$ Qataba > Al-Ruays; Al-Mokha; South Mokha > Al-Haymah > Zahari.

\section{Nickel (Ni)}

Nickel can enter the environment naturally through weathering of minerals and rocks and through anthropogenic sources [41]. Nickel is one of the largest trace metal constituents of crude oil [42], it is used extensively in industry and its large uses like Ni-Cd rechargeable battery, and hence its presence in high concentration in marine environments may indicate direct input from oil pollutants. From the Table 3, in the sediments of the present study areas the concentrations of Ni ranged between ND in the sediments of stations (24 \& 37) at Al-Ruays and South Al-Mokha regions, and $39.33 \mu \mathrm{g} / \mathrm{g}$ of station (10) at Khowkhah region, with general average $(8.98 \mu \mathrm{g} / \mathrm{g})$.

The present values of $\mathrm{Ni}$ in the sediments are lower than and the background value (Shale), and lower than in those reported by each of Heba [16], Heba \& Al-Mudaffer [38] \& Al-Edresy [1,39]. The highest content of Ni was recorded at Al-Khowkhah and AlMokha regions, which means that, the high nickel concentrations are certainly anthropogenic from the direct human impact from the boats. From the Figure 2 the percentage distribution of nickel contents in the sediments of the present study areas showed that the contents are arranged according to their abundance as follows: Al-Khowkhah > Al-Mokha > Yokhtul > Abu-Zahr > AlHaymah; North Mokha > Qataba; Moushij; Zahari > Al-Ruays; South Mokha.

\section{Lead $(\mathrm{Pb})$}

Lead is among the most pervasive of pollutants has introduced to the marine environment due to human activities. In local coastal regions, lead pollution may also be present in sewage contamination [43]. Anthropogenic outputs of lead to the environment outweigh all-natural sources. $\mathrm{Pb}$ reaches the 
aquatic environment through precipitation, fall-out of lead dust and municipal wastewater discharges [44].From the Table 3, in the sediments of this study areas the concentrations of $\mathrm{Pb}$ ranged between $0.15 \mu \mathrm{g} / \mathrm{g}$ in the sediments of stations (24) at Al-Ruays region, and $30.31 \mu \mathrm{g} / \mathrm{g}$ of station (27) at Yakhtul region, with general average $(6.47 \mu \mathrm{g} / \mathrm{g})$.

The present values of $\mathrm{Pb}$ in the sediments are lower than the background value (Shale), except of in three stations (10, 14) in Al-Khowkhah region and station (27) in Yakhtul region. From Figure 2, it was noticed that the percentage distribution of $\mathrm{Pb}$ content in Yakhtul, Al-Khowkhah and Al-Mokha sediments is like that of $\mathrm{Ni}$, where the $\mathrm{Pb}$ content increases because of the influence of boats and other wastes. The percentage distribution of lead contents (Figure 2) showed that the $\mathrm{Pb}$ contents are arranged according to their abundance as follows: Yokhtul > Al-Khowkhah; South Mokha > Al-Mokha > Al-Haymah > Qataba; Zahari > Moushij > Abu-Zahr > Al-Ruays > North Mokha.

\section{Assessment of potential ecological risk}

Heavy metals in sediments persist in the environment and can be set up not only to the benthic organisms, but also for aquatic organisms and dangerous because the metals in the sediment can be released in the overlying water. A variety of minerals and basic elements of biology, but they have a negative effect on living organisms if their concentrations exceed certain thresholds. Minerals associated with the sediment can accumulate in the tissues of marine organisms, and it could be possible that adversely affects the rights in all parts of the food chain. Thus, compared with the concentrations of metals contamination factor (CF), potential ecological risk (Ei) and potential ecological risk index (RI) so that we can evaluate the mineral risks to the environment.

Minerals in rocks and minerals are harmless and usually only become potentially toxic when dissolved in water [45]. A tidal flat play an important role in the hydrological and ecological processes in the coastal region, which is also ideal for wildlife, fishing and recreation environment [46]. Proper assessment of pollution of heavy metals in the sediments of the Red Sea in Yemen is a critical issue to provide successful management of marine ecosystems.

\section{Contamination factor (CF)}

The empirical index provides a comparative means for assessing the level of heavy metal pollution [47]. The values of contamination factor (CF) for the heavy metals for all samples are presented in Table 4. The results showed that obtained from the contamination factor (CF) calculation for heavy metals $(\mathrm{Cu}$, $\mathrm{Cd}, \mathrm{Zn}, \mathrm{Ni}, \mathrm{Pb}, \mathrm{Co}$ and $\mathrm{Mn}$ ) in this study that the contamination factor values for these elements were in the range $(0.04-1.45)$ with general average $(0.39)$ for $\mathrm{Cu},(0.00-6.67)$ with general average (2.53) for $\mathrm{Cd},(0.03-0.96)$ with general average (0.39) for $\mathrm{Zn},(0.00-0.58)$ with general average $(0.13)$ for $\mathrm{Ni},(0.01$ - 1.52) with general average $(0.32)$ for $\mathrm{Pb},(0.00-0.61)$ with general average $(0.18)$ for Co and $(0.00-1.40)$ with general average (0.43) for $\mathrm{Mn}$.

Table 4: Results of Contamination factor (CF) of sediments from the south of Yemen's Red Sea coast (Al-Haymah - Al-Mokha).

\begin{tabular}{|c|c|c|c|c|c|c|c|c|}
\hline \multirow{2}{*}{ Regions } & \multirow{2}{*}{ Stations No } & $\mathrm{Cu}$ & Cd & $\mathbf{Z n}$ & $\mathbf{N i}$ & $\mathbf{P b}$ & Co & Mn \\
\hline & & \multicolumn{7}{|c|}{ CF } \\
\hline \multirow{3}{*}{ Al-Haymah } & 1 & 0.23 & 1.67 & 0.38 & 0.16 & 0.08 & 0.26 & 0.26 \\
\hline & 2 & 0.62 & 1.1 & 0.11 & 0 & 0.65 & 0.14 & 0.14 \\
\hline & Average & 0.43 & 1.39 & 0.25 & 0.08 & 0.37 & 0.2 & 0.2 \\
\hline Qataba & 3 & 0.21 & 5.57 & 0.39 & 0.08 & 0.27 & 0.14 & 0.43 \\
\hline \multirow{5}{*}{ Abu-Zahr } & 4 & 0.21 & 2.23 & 0.32 & 0 & 0.02 & 0.14 & 1.4 \\
\hline & 5 & 0.16 & 3.33 & 0.37 & 0.21 & 0.15 & 0.38 & 0.33 \\
\hline & 6 & 0.21 & 2.77 & 0.38 & 0.12 & 0.48 & 0.25 & 0.3 \\
\hline & 7 & 0.21 & 3.33 & 0.59 & 0.06 & 0.22 & 0.26 & 0.63 \\
\hline & Average & 0.2 & 2.92 & 0.42 & 0.1 & 0.22 & 0.26 & 0.67 \\
\hline \multirow{8}{*}{ Al-Khowkhah } & 8 & 1.24 & 1.1 & 0.36 & 0.01 & 0.1 & 0.07 & 0.42 \\
\hline & 9 & 0.34 & 4.43 & 0.68 & 0.28 & 0.19 & 0.03 & 0.6 \\
\hline & 10 & 0.42 & 5 & 0.48 & 0.58 & 1.17 & 0.16 & 0.51 \\
\hline & 11 & 0.07 & 0.57 & 0.49 & 0.57 & 0.12 & 0.35 & 0.61 \\
\hline & 12 & 0.21 & 1.1 & 0.5 & 0.04 & 0.08 & 0.11 & 0.49 \\
\hline & 13 & 0.41 & 0 & 0.23 & 0.08 & 0.11 & 0.16 & 0.75 \\
\hline & 14 & 0.07 & 2.17 & 0.29 & 0.43 & 1.33 & 0.15 & 0.2 \\
\hline & Average & 0.39 & 2.05 & 0.43 & 0.28 & 0.44 & 0.15 & 0.51 \\
\hline
\end{tabular}


Ecology \& Conservation Science: Open Access

\begin{tabular}{|c|c|c|c|c|c|c|c|c|}
\hline \multirow{3}{*}{ Mawshij } & 15 & 0.62 & 0.57 & 0.52 & 0.08 & 0.25 & 0.28 & 0.98 \\
\hline & 16 & 0.29 & 1.1 & 0.55 & 0.06 & 0.23 & 0.05 & 0.5 \\
\hline & Average & 0.46 & 0.84 & 0.54 & 0.07 & 0.24 & 0.17 & 0.74 \\
\hline \multirow{5}{*}{ Zahari } & 17 & 0.41 & 2.23 & 0.25 & 0 & 0.15 & 0.23 & 0.56 \\
\hline & 18 & 0.21 & 3.33 & 0.03 & 0.01 & 0.13 & 0.12 & 0.28 \\
\hline & 19 & 0.62 & 1.1 & 0.46 & 0.03 & 0.12 & 0.11 & 0.28 \\
\hline & 20 & 0.11 & 2.2 & 0.17 & 0.23 & 0.65 & 0 & 0.15 \\
\hline & Average & 0.34 & 2.22 & 0.23 & 0.07 & 0.26 & 0.12 & 0.32 \\
\hline \multirow{5}{*}{ Al-Ruays } & 21 & 1.24 & 1.67 & 0.46 & 0.03 & 0.18 & 0.12 & 0.28 \\
\hline & 22 & 0.13 & 1.67 & 0.22 & 0.1 & 0.13 & 0.28 & 0.27 \\
\hline & 23 & 0.77 & 5.57 & 0.34 & 0.07 & 0.32 & 0.26 & 0.7 \\
\hline & 24 & 0.06 & 3.37 & 0.28 & 0 & 0.01 & 0.14 & 0.2 \\
\hline & Average & 0.55 & 3.07 & 0.33 & 0.05 & 0.16 & 0.2 & 0.36 \\
\hline \multirow{6}{*}{ Yakhtul } & 25 & 0.04 & 2.77 & 0.16 & 0.18 & 0.05 & 0.03 & 0.17 \\
\hline & 26 & 0.63 & 0 & 0.62 & 0.04 & 0.13 & 0.23 & 0.7 \\
\hline & 27 & 0.24 & 1.67 & 0.55 & 0.19 & 1.52 & 0 & 0.51 \\
\hline & 28 & 0.27 & 1.07 & 0.48 & 0.11 & 0.74 & 0.14 & 0.42 \\
\hline & 29 & 0.07 & 1.1 & 0.29 & 0.32 & 0.52 & 0.56 & 0.29 \\
\hline & Average & 0.25 & 1.32 & 0.42 & 0.17 & 0.59 & 0.19 & 0.42 \\
\hline \multirow{5}{*}{ North Al-Mokha } & 30 & 0.21 & 0.57 & 0.34 & 0.03 & 0.07 & 0.61 & 0.5 \\
\hline & 31 & 0.04 & 2.77 & 0.28 & 0.25 & 0.08 & 0.23 & 0.17 \\
\hline & 32 & 0.21 & 5.57 & 0.96 & 0.04 & 0.03 & 0.14 & 0.42 \\
\hline & 33 & 0.83 & 6.67 & 0.48 & 0.03 & 0.07 & 0.12 & 0.28 \\
\hline & Average & 0.32 & 3.9 & 0.52 & 0.09 & 0.06 & 0.28 & 0.34 \\
\hline \multirow{3}{*}{ Al-Mokha } & 34 & 1.45 & 3.33 & 0.36 & 0.01 & 0.08 & 0.09 & 0.49 \\
\hline & 35 & 0.1 & 6.57 & 0.29 & 0.35 & 0.69 & 0.16 & 0.39 \\
\hline & Average & 0.78 & 4.95 & 0.33 & 0.18 & 0.39 & 0.13 & 0.44 \\
\hline \multirow{3}{*}{ South Al- Mokha } & 36 & 0.05 & 2.27 & 0.26 & 0.1 & 0.77 & 0.02 & 0.13 \\
\hline & 37 & 1.06 & 2.23 & 0.39 & 0 & 0.12 & 0.11 & 0 \\
\hline & Average & 0.56 & 2.25 & 0.33 & 0.05 & 0.45 & 0.07 & 0.07 \\
\hline Min & -37 & 0.04 & 0 & 0.03 & 0 & 0.01 & 0 & 0 \\
\hline Max & & 1.45 & 6.67 & 0.96 & 0.58 & 1.52 & 0.61 & 1.4 \\
\hline Area average & & 0.39 & 2.53 & 0.39 & 0.13 & 0.32 & 0.18 & 0.43 \\
\hline \multicolumn{2}{|c|}{ Background in Shale } & 45 & 0.3 & 95 & 68 & 20 & 19 & 850 \\
\hline \multicolumn{2}{|c|}{ Sediment Quality of Study Area } & L to $\mathrm{M}$ & L to $\mathrm{V}$ & $\mathrm{L}$ & $\mathrm{L}$ & L to $\mathrm{M}$ & $\mathrm{L}$ & $\mathrm{L}$ to $\mathrm{M}$ \\
\hline
\end{tabular}

The contamination factor values for heavy metals in the sediments of the present study areas are arranged according to their dangerous as follows: $\mathrm{Cd}>\mathrm{Mn}>\mathrm{Cu}$; $\mathrm{Zn}>\mathrm{Pb}>\mathrm{Co}>\mathrm{Ni}$, and the contamination factor values for heavy metals, according to the order the evaluation of pollution in the various regions as follows: (Al-Mokha > South Al-Mokha > Al-Ruays > Moushij > AlHaymah $>$ Al-Khowkhah $>$ Zahari $>$ North Al-Mokha $>$ Yokhtul $>$ Qataba > Abu-Zahr) for Cu, (Qataba > Al-Mokha > North AlMokha $>$ Al-Ruays $>$ Abu-Zahr $>$ South Al-Mokha $>$ Zahari $>$ AlKhowkhah $>$ Al-Haymah $>$ Yokhtul $>$ Moushij) for Cd, (Moushij $>$ North Al-Mokha $>$ Al-Khowkhah $>$ Abu-Zahr; Yokhtul $>$ Qataba $>$
Al-Ruays; Al-Mokha; South Al-Mokha > Al-Haymah > Zahari) for Zn, (Al-Khowkhah $>$ Al-Mokha $>$ Yokhtul $>$ Abu-Zahr $>$ North AlMokha > Al-Haymah; Qataba > Moushij; Zahari > Al-Ruays; South Al-Mokha) for Ni, (Yokhtul > South Al-Mokha > Al-Khowkhah > Al-Mokha $>$ Al-Haymah $>$ Qataba $>$ Zahari $>$ Moushij $>$ Abu-Zahr $>$ Al-Ruays > North Al-Mokha) for Pb, (North Al-Mokha > AbuZahr $>$ Al-Haymah; Al-Ruays $>$ Yokhtul $>$ Moushij $>$ Al-Khowkhah $>$ Qataba > Al-Mokha > Zahari > South Al-Mokha) for Co and (Moushij > Abu-Zahr $>$ Al-Khowkhah $>$ Al-Mokha $>$ Qataba $>$ Yokhtul $>$ Al-Ruays $>$ North Al-Mokha $>$ Zahari $>$ Al-Haymah $>$ South Al-Mokha) for Mn. 


\section{Ecology \& Conservation Science: Open Access}

The classification of contamination factor for all metals except the Cd low classification is located between a Low Contamination and Moderate Contamination in terms both of $\mathrm{Zn}, \mathrm{Ni}$ and Co with classification Low Contamination and $\mathrm{Cu}$, $\mathrm{Pb}$ and $\mathrm{Mn}$ with classification Moderate Contamination while Cd with classification from Low Contamination to Very high Contamination. The analysis indicates that the sediments are polluted with $\mathrm{Cd}$ and act as a sink for heavy metals contributed by a multitude of anthropogenic sources [48].

\section{Potential ecological risk $\left(E_{i}\right)$}

The values of potential ecological risk $\left(E_{i}\right)$ for the heavy metals for all samples are presented in Table 5. The results showed that obtained from the potential ecological risk $\left(E_{i}\right)$ calculation for only five heavy metals ( $\mathrm{Cu}, \mathrm{Cd}, \mathrm{Zn}, \mathrm{Ni}$ and $\mathrm{Pb}$ ) in this study that the potential ecological risk $\left(\mathrm{E}_{\mathrm{i}}\right)$ values for these elements were in the range $(0.20-7.25)$ with general average (1.39) for $\mathrm{Cu},(0.00-200.10)$ with general average (76.03) for $\mathrm{Cd},(0.03-0.96)$ with general average $(0.39)$ for $\mathrm{Zn},(0.00-2.90)$ with general average $(0.66)$ for $\mathrm{Ni}$ and $(0.05-7.60)$ with general average (1.62) for $\mathrm{Pb}$.

The potential ecological risk $\left(E_{i}\right)$ values for heavy metals in the sediments of the present study areas are arranged according to their evaluation of dangerous as follows: $\mathrm{Cd}>\mathrm{Cu}>\mathrm{Pb}>\mathrm{Ni}$ $>\mathrm{Zn}$. The classification of potential ecological risk is located between Low Risk and Disastrous Risk, where it's were classified of $\mathrm{Cu}, \mathrm{Zn}, \mathrm{Ni}$ and $\mathrm{Pb}$ are Low Risk, and classification of $\mathrm{Cd}$ from Low Risk to Disastrous Risk, stations that were rated low risk for Cd was concentrations values zero (ND). Qataba, Al-Mokha and North Al-Mokha regions were recorded the highest classification in the potential ecological risk for the $\mathrm{Cd}$.

Table 5: Results of the potential ecological risk $\left(E_{i}\right)$ and the potential ecological risk index (RI) of coastal sediments from the south of Yemen's Red Sea coast (Al-Haymah - Al-Mokha).

\begin{tabular}{|c|c|c|c|c|c|c|c|}
\hline \multirow{2}{*}{ Regions } & \multirow{2}{*}{ Stations No } & \multicolumn{5}{|c|}{$E_{i}$} & \multirow{2}{*}{ RI } \\
\hline & & $\mathrm{Cu}$ & Cd & Zn & $\mathbf{N i}$ & $\mathbf{P b}$ & \\
\hline \multirow{3}{*}{ Al-Haymah } & 1 & 1.15 & 50.1 & 0.38 & 0.8 & 0.4 & 52.83 \\
\hline & 2 & 3.1 & 33 & 0.11 & 0 & 3.25 & 39.46 \\
\hline & Average & 2.13 & 41.55 & 0.25 & 0.4 & 1.83 & 46.15 \\
\hline Qataba & 3 & 1.05 & 167.1 & 0.39 & 0.4 & 1.35 & 170.29 \\
\hline \multirow{5}{*}{ Abu-Zahr } & 4 & 1.05 & 66.9 & 0.32 & 0 & 0.1 & 68.37 \\
\hline & 5 & 0.8 & 99.9 & 0.37 & 1.05 & 0.75 & 102.87 \\
\hline & 6 & 1.05 & 83.1 & 0.38 & 0.6 & 2.4 & 87.53 \\
\hline & 7 & 1.05 & 99.9 & 0.59 & 0.3 & 1.1 & 102.94 \\
\hline & Average & 0.99 & 87.45 & 0.42 & 0.49 & 1.09 & 90.43 \\
\hline \multirow{8}{*}{ Al-Khowkhah } & 8 & 6.2 & 33 & 0.36 & 0.05 & 0.5 & 40.11 \\
\hline & 9 & 1.7 & 132.9 & 0.68 & 1.4 & 0.95 & 137.63 \\
\hline & 10 & 2.1 & 150 & 0.48 & 2.9 & 5.85 & 161.33 \\
\hline & 11 & 0.35 & 17.1 & 0.49 & 2.85 & 0.6 & 21.39 \\
\hline & 12 & 1.05 & 33 & 0.5 & 0.2 & 0.4 & 35.15 \\
\hline & 13 & 2.05 & 0 & 0.23 & 0.4 & 0.55 & 3.23 \\
\hline & 14 & 0.35 & 65.1 & 0.29 & 2.15 & 6.65 & 74.54 \\
\hline & Average & 1.97 & 61.59 & 0.43 & 1.42 & 2.21 & 67.63 \\
\hline \multirow{3}{*}{ Mawshij } & 15 & 3.1 & 17.1 & 0.52 & 0.4 & 1.25 & 22.37 \\
\hline & 16 & 1.45 & 33 & 0.55 & 0.3 & 1.15 & 36.45 \\
\hline & Average & 2.28 & 25.05 & 0.54 & 0.35 & 1.2 & 29.41 \\
\hline \multirow{5}{*}{ Zahari } & 17 & 2.05 & 66.9 & 0.25 & 0 & 0.75 & 69.95 \\
\hline & 18 & 1.05 & 99.9 & 0.03 & 0.05 & 0.65 & 101.68 \\
\hline & 19 & 3.1 & 33 & 0.46 & 0.15 & 0.6 & 37.31 \\
\hline & 20 & 0.55 & 66 & 0.17 & 1.15 & 3.25 & 71.12 \\
\hline & Average & 1.69 & 66.45 & 0.23 & 0.34 & 1.31 & 70.02 \\
\hline \multirow{5}{*}{ Al-Ruays } & 21 & 6.2 & 50.1 & 0.46 & 0.15 & 0.9 & 57.81 \\
\hline & 22 & 0.65 & 50.1 & 0.22 & 0.5 & 0.65 & 52.12 \\
\hline & 23 & 3.85 & 167.1 & 0.34 & 0.35 & 1.6 & 173.24 \\
\hline & 24 & 0.3 & 101.1 & 0.28 & 0 & 0.05 & 101.73 \\
\hline & Average & 2.75 & 92.1 & 0.33 & 0.25 & 0.8 & 96.23 \\
\hline
\end{tabular}


Ecology \& Conservation Science: Open Access

\begin{tabular}{|c|c|c|c|c|c|c|c|}
\hline \multirow{6}{*}{ Yakhtul } & 25 & 0.2 & 83.1 & 0.16 & 0.9 & 0.25 & 84.61 \\
\hline & 26 & 3.15 & 0 & 0.62 & 0.2 & 0.65 & 4.62 \\
\hline & 27 & 1.2 & 50.1 & 0.55 & 0.95 & 7.6 & 60.4 \\
\hline & 28 & 1.35 & 32.1 & 0.48 & 0.55 & 3.7 & 38.18 \\
\hline & 29 & 0.35 & 33 & 0.29 & 1.6 & 2.6 & 37.84 \\
\hline & Average & 1.25 & 39.66 & 0.42 & 0.84 & 2.96 & 45.13 \\
\hline \multirow{5}{*}{$\begin{array}{l}\text { North Al- } \\
\text { Mokha }\end{array}$} & 30 & 1.05 & 17.1 & 0.34 & 0.15 & 0.35 & 18.99 \\
\hline & 31 & 0.2 & 83.1 & 0.28 & 1.25 & 0.4 & 85.23 \\
\hline & 32 & 1.05 & 167.1 & 0.96 & 0.2 & 0.15 & 169.46 \\
\hline & 33 & 4.15 & 200.1 & 0.48 & 0.15 & 0.35 & 205.23 \\
\hline & Average & 1.61 & 116.85 & 0.52 & 0.44 & 0.31 & 119.73 \\
\hline \multirow{3}{*}{ Al-Mokha } & 34 & 7.25 & 99.9 & 0.36 & 0.05 & 0.4 & 107.96 \\
\hline & 35 & 0.5 & 197.1 & 0.29 & 1.75 & 3.45 & 203.09 \\
\hline & Average & 3.88 & 148.5 & 0.33 & 0.9 & 1.93 & 155.53 \\
\hline \multirow{3}{*}{$\begin{array}{l}\text { South Al- } \\
\text { Mokha }\end{array}$} & 36 & 0.25 & 68.1 & 0.26 & 0.5 & 3.85 & 72.96 \\
\hline & 37 & 5.3 & 66.9 & 0.39 & 0 & 0.6 & 73.19 \\
\hline & Average & 2.78 & 67.5 & 0.33 & 0.25 & 2.23 & 73.08 \\
\hline Min & -37 & 0.20 & 0.00 & 0.03 & 0.00 & 0.05 & 3.23 \\
\hline Max & & 7.25 & 200.10 & 0.96 & 2.90 & 7.60 & 205.23 \\
\hline Area Average & & 1.93 & 76.03 & 0.39 & 0.66 & 1.62 & 80.63 \\
\hline \multicolumn{2}{|c|}{ Sediment Quality of Study Area } & LR & LR to DR & LR & LR & LR & LR to VHR \\
\hline
\end{tabular}

\section{Potential ecological risk index (RI):}

The values of potential ecological risk index (RI) for the heavy metals for all samples are presented in Table 5. The results showed that obtained from the potential ecological risk index (RI) calculation for heavy metals $(\mathrm{Cu}, \mathrm{Cd}, \mathrm{Zn}, \mathrm{Ni}$ and $\mathrm{Pb}$ ) in this study that the potential ecological risk index (RI), values for these elements were in the ranged from 3.23 at station (13) in Al-Khowkhah region, to 205.23 at station (33) in North AlMokha region, with general average 80.63 for study area.

The potential ecological risk values for heavy metals, according to the order evaluation of pollution in the various regions of as follows: (Qataba > Al-Mokha > North Al-Mokha > Al-Ruays $>$ Abu-Zahr $>$ South Al-Mokha $>$ Zahari $>$ Al-Khowkhah $>$ Al-Haymah $>$ Yokhtul $>$ Moushij). Lower values were in the stations where cadmium concentrations did not score $(\mathrm{Cd}=\mathrm{ND})$. The regions study is classification by potential ecological risk index as follows; Al-Haymah, Abu-Zahr, Al-Khowkhah, Moushij, Zahari, Al-Ruays, Yokhtul and South Al-Mokha regions were low risk, North Al-Mokha region was moderate risk and Qataba and Al-Mokha regions were considerable risk.

\section{Summary}

From, the foregoing, one can see:

a) The present study showed that the study area which located between Al-Haymah and Al-Mokha south Red Sea, Yemen non polluted by heavy metals $(\mathrm{Cu}, \mathrm{Zn}, \mathrm{Ni}, \mathrm{Pb}$, Co and
$\mathrm{Mn}$ ) in sediment, while cadmium (Cd) record high pollution in this area especially in Al-Mokha.

b) Cadmium (Cd) record high levels of pollution in all study stations but stations in which did not record any level of contamination was reason for this is that the values of $\mathrm{Cd}$ $=\mathrm{ND}$.

c) Al-Mokha region it is more areas pollution that's compatible with the great human activity in comparison with the rest of the study areas, most prominent of these activities is a commercial port and fishing port. Also, the city of Al-Mokha is the largest study areas densely populated.

d) Station (34) which is in the commercial port basin and station (33) which is located close to the commercial port were recorded the highest values for most heavy metals this prove that the commercial port is the largest source of pollution in this study.

\section{Statistical analysis}

\section{Correlation analysis}

The interrelationships matrices between the studied elements in the costal sediments between Al-Haymah and AlMokha, South Red Sea, Yemen are calculated and are shown in Table 6. Various degrees of correlations were found some significant correlations, both positive and negative between the heavy metal, gravel, sand, mud, organic matter and calcium carbonate in study area showed. 
Table 6: Correlation coefficients between the grain size, organic matter $(\mathrm{OM})$, calcium carbonate $\left(\mathrm{CaCo}_{3}\right)$ and heavy metals in of coastal sediments from the south of Yemen's Red Sea coast (Al-Haymah - Al-Mokha).

\begin{tabular}{|c|c|c|c|c|c|c|c|c|c|c|}
\hline & Gravel & Sand & Mud & OM & $\mathrm{CaCo}_{3}$ & $\mathrm{Cu}$ & Cd & $\mathbf{Z n}$ & $\mathbf{N i}$ & $\mathrm{Pb}$ \\
\hline Gravel & 1 & & & & & & & & & \\
\hline Sand & $-0.64^{* *}$ & 1 & & & & & & & & \\
\hline Mud & $-0.61^{* *}$ & -0.22 & 1 & & & & & & & \\
\hline OM & $-0.37^{*}$ & -0.04 & $0.54^{* *}$ & 1 & & & & & & \\
\hline $\mathrm{CaCo}_{3}$ & $-0.43^{*}$ & -0.13 & $0.68^{* *}$ & $0.48^{*}$ & 1 & & & & & \\
\hline $\mathrm{Cu}$ & 0.28 & -0.27 & -0.13 & 0.26 & 0.17 & 1 & & & & \\
\hline Cd & -0.31 & $0.40^{*}$ & -0.09 & $0.31^{*}$ & 0.16 & $0.42^{*}$ & 1 & & & \\
\hline Zn & -0.15 & $0.42^{*}$ & -0.26 & $-0.73^{* *}$ & -0.24 & -0.29 & -0.07 & 1 & & \\
\hline $\mathbf{N i}$ & $-0.39 *$ & $0.53^{* *}$ & -0.03 & -0.06 & -0.15 & 0.02 & 0.09 & 0.2 & 1 & \\
\hline $\mathbf{P b}$ & 0.19 & -0.12 & -0.06 & 0.04 & 0.16 & 0.09 & $-0.36^{*}$ & -0.21 & $0.52^{* *}$ & 1 \\
\hline
\end{tabular}

From the Table 6:

a) Gravel is negative significantly related with each of Sand, Mud, $\mathrm{OM}$ and $\mathrm{CaCo}_{3}$ and the Mud shows very good association with each of $\mathrm{OM}$ and $\mathrm{CaCo}_{3}(\mathrm{r}=0.54 \& 0.68)$, while the $\mathrm{OM}$ is good positively related with $\mathrm{CaCo} 3(\mathrm{r}=0.48)$.

b) Sand is positively related with $\mathrm{Cd}, \mathrm{Zn}$ and $\mathrm{Ni}(\mathrm{r}=0.40$, 0.42 and 0.53 ), while the gravel shows negative significantly related with $\mathrm{Ni}(\mathrm{r}=-0.39)$, also the OM shows positively related with $\mathrm{Cd}$ and $\mathrm{Cu}(\mathrm{r}=0.31$ and 0.26$)$ and negatively related for $\mathrm{OM}$ with $\mathrm{Zn}(\mathrm{r}=-0.73$ ), while $\mathrm{CaCo} 3$ shows insignificant relationship with $\mathrm{Zn}(\mathrm{r}=-0.24)$.

c) The sediment is of low mud content, almost no clear metal association with mud, except of shows insignificant relationship with $\mathrm{Zn}(\mathrm{r}=-0.26)$.

d) Cd shows good relationship with each of sand, OM and $\mathrm{Cu}(\mathrm{r}=0.40,0.31$ and 0.42$)$ and negatively with gravel and $\mathrm{Pb}(\mathrm{r}=-0.31$ and -0.36$)$.

e) Zn shows better relationship with sand $(r=0.42)$, and very good negative relationship with $\mathrm{OM}(\mathrm{r}=-0.73)$, while shows insignificant relationship with other elements.

f) Ni shows good positive relationship with sand and $\mathrm{Pb}$ $(r=0.53$ and 0.52 ), while no association with others of the metals.

g) $\mathrm{Pb}$ shows significant positive relationship with $\mathrm{Ni}(\mathrm{r}=$ 0.52), while negative relationship with $\mathrm{Cd}(\mathrm{r}=-0.36)$ [49$51]$.

\section{Conclusion}

This study was carried out to provide information on heavy metal concentrations and Ecological Risk Assessment for these metals in coastal sediment between Al-Haymah and Al-Mokha, South Red Sea, Yemen. Distribution and ecological risk for $\mathrm{Cu}$, $\mathrm{Cd}, \mathrm{Zn}, \mathrm{Ni}$ and $\mathrm{Pb}$ in sediment samples collected from 11 regions
(37 stations) in the coasts of Yemen were studied. The results showed that the most of sediments are sand (83.83\%), the content of organic matter was low $(1.4 \%)$ and rich of calcium carbonate $(56.1 \%)$ while the concentrations of heavy metals were less than the Background value (shale) except the $\mathrm{Cd}$ record high concentrations in all study stations but stations in which did not record any level of concentration was reason for this is that the values of $\mathrm{Cd}=\mathrm{ND}$. The present study shows that the coastal sediments in this part of the Red Sea coast of Yemen are not Polluted by heavy metals $\mathrm{Cu}, \mathrm{Zn}, \mathrm{Ni}$ and $\mathrm{Pb}$, but it heavily polluted by Cd, especially in Al-Mokha, where arrived value RI = 205.23 in station (33).

The contamination factor values for heavy metals arranged according to their dangerous as follows: $\mathrm{Cd}>\mathrm{Cu}>\mathrm{Zn}>\mathrm{Pb}>\mathrm{Ni}$ and the potential ecological risk index values for heavy metals, according to the order evaluation of pollution in the various regions as follows: (Qataba > Al-Mokha > North Al-Mokha $>\mathrm{Al}-$ Ruays $>$ Abu-Zahr $>$ South Al-Mokha $>$ Zahari $>$ Al-Khowkhah $>$ Al-Haymah $>$ Yokhtul $>$ Moushij). Consequently, continuous monitoring and efforts of remediation are might be required to improve the coastal environment near the high human activity's areas.

\section{Recommendations}

a) We recommend the competent authorities to move quickly to combat pollution, especially cadmium pollution in the region and through the work of many studies that confirm the source of this element and reduce it.

b) Continue doing a lot of future studies of the study area and the coast of Yemen in general, and to monitor the levels of heavy metals, especially cadmium.

c) In further studies, environmental and human health risk posed by these metals pollution in sediment will be assessed in the coast of Yemen to evaluate adverse effects of contaminated sediments. 


\section{Ecology \& Conservation Science: Open Access}

\section{References}

1. Al-Edresy M A (2012) Impacts of Man-Made Activities on The Red Sea Coastal Waters off Al-Hudaydah (Yemen) Ph.D. Thesis Fac Sci Alexandria University pp 327.

2. Al-Hagibi HA, Al-Selwi KM, Nagi HM, Al-Shwafi NA (2018) Assessmnt of Heavy Metals Concentration in Mangroves Leaves of the Red Sea Coast of Yemen. J Ecology \& Natural Resources 2(1): 120.

3. Bervoets L, Panis L, Verheyen R (1994) Trace metal levels in water, sediment and Chironomus grthumni, from different water courses in Flanders (Belgium). Chemosphere 29: 1591-1601.

4. Bruder H, Lagarde F, Leroy M, Conghanowr C, Engelhard F (2002) Application of a Sequential extraction procedure to study the release of elements from municipal solid waste Incineration bottom ash. Anal Chim Acta 451(2): 285-295.

5. Al-Hagibi HA, Al-Selwi KM, Nagi HM, Al-Shwafi NA (2018) Study of Heavy Metals contamination in Mangrove Sediments of the Red Sea Coast of Yemen from Al-Salif to Bab-el-Mandeb Strait. J Ecology \& Natural Resources 2(1): 121.

6. El-Rayis 0 (2005) Impact of Man's activities on a closed fishing Lake, Lake Maryout in Egyp as a case study. Mitigation and Adaptation Strateg Glob Change 10(1): 145-157.

7. Al-Hagibi HA (2017) Study of Some Heavy Metals Concentrations in Mangroves Environment - Red Sea Coast of Yemen. M.Sc. Thesis Fac Sci Sana'a Univer p. 200.

8. Chester R, Voutsinou FG (1981) The initial assessment of trace metal pollution in coastal sediments. Mar Pollut Bull 12(3): 84-91.

9. Badr NB, El-Fiky A, Mostafa A, Al-Mur BA (2009) Metal pollution records in core sediments of some Red Sea coastal areas, Kingdom of Saudi Arabia. Environ. Monit Assess 155(1-4): 509-526.

10. Sarkar S, Franciskovic-Bilinski S, Bhattacharya A, Saha M, Bilinski H (2004). Levels of elements in the surficial estuarine sediments of the Hugli River, northeast India and their environmental implications. Environ International 30(8): 1089-1098.

11. Abu Khatita A, Shaker I, Zawahry El M and Shetaia S (2016). Distribution and ecological risk assessment of heavy metals in the sediment cores from Manzala lagoon, Egypt. IJISET International J Innovative Sci Engineering and Technol 3(4): 377-387.

12. Nijenhuis I, Bosch H, Sinninghe J, Burmsack H, de Lange GJ (1999) Organic matter and trace element rich sapropels and black shales: a geochemical comparsion. Earth and Planetary Sci Letters 169: 277 290.

13. Bryan GW (1976) Metal concentration in the sea. Mar Pollut Bull 7:353-356.

14. Calace N, Ciardullo S, Petronio B, Pietrantonio M, Abbondanzi F, et al. (2005) Influence of chemical parameters (heavy metals, organic matter, sulphur and nitrogen) on toxicity of sediments from the Mar Piccolo (Taranto, Ionian Sea, Italy). Microchemical J 79(1-2): 243-248.

15. El-Anbaawy MI, Al-Awah MA (1993) Opaque mineralogy of some beach sand, Yemen Red Sea coastal areas. Egypt J Geol 37(2): 39-52.

16. Heba HM, Al-Edresy MA, Al-Saad HT, Abdelmoneim M (2004) Background levels of heavy metals in dissolved, particulate phases of water and sediment of Al-Hudaydah Red Sea coast of Yemen. J KAU Mar Sci 15(1): 53-71.

17. Wasel SO (2008) Sedimentological and geoenvironmental evaluation of the coastal area between Al-Khowkhah and Al-Mokha, Red Sea, Republic of Yemen. Ph.D. Thesis Fac Sci Assiut Uni, p. 215.

18. Sagheer AA (2013) Geochemistry in surface sediments of the Kwar Katib lagoon, Red sea, Yemen. J Environ Res Manag 4(4): 242-248.
19. El-Shenawy MA, Farag AM (2005) Spatial and temporal variability of saprophytic and water quality bacteria along the coast of Aqaba, Suez Gulfs and Red Sea-Egypt. Egy J Aqua Res 31(1): 157-169.

20. Vogel M (1978) Textbook of quantitative inorganic analysis, 4 ed printed in Great Britian by Willian Clowes limited Beccles and London 92: 492-493.

21. Strickland J, Parsons T (1968) Practical handbook of seawater analysis fisheries research board of Canada, p. 432.

22. UNEP/IAEA (1986) Reference methods for marine pollution studies, No. 39 , p. 6.

23. Håkanson L (1980) Ecological risk index for aquatic pollution control, a sedimentological approach. Water Res 14(8): 975-1001.

24. Savvides C, Papadopoulos A, Haralambous K, Loizidou M (1995) Sea sediments contaminated with heavy metals: metal speciation and removal. Wat Sci Tech 32(9-10): 65-73.

25. Hilton J, Davison W, Ochsenbein U (1985) A mathematical model for analysis of sediment coke data. Chem Geol 48: 281-291.

26. Wang Y, Yang Z, Shen Z, Tang Z, Niu J, et al. (2011) Assessment of heavy metals in sediments from a typical catchment of the Yangtze River, China. Environ Monit Assess 172(1-4): 407-417.

27. Abu Khatita AM (2011) Assessment of soil and sediment contamination in the Middle Nile Delta area (Egypt)-Geo-Environmental study using combined sedimentological, geophysical and geochemical methods. Ph.D. Thesis Fac Sci Alexandria Uni, p. 214.

28. Seshan B, Natesan U, Deepthi K (2010) Geochemical and statistical approach for evaluation of heavy metal pollution in core sediments in southeast coast of India. Int. J Environ Sci Tech 7(2): 291-306.

29. Al-Saad HT, Al-Khafaji B, Sultan A (1996) Distribution of trace metals in water, sediments and biota samples from Shatt Al-Arab estuary. Mar Meso 11: 63-77.

30. El-Serehy H, Aboulela H, Al-Misned F, Kaiser M, Al-Rasheid K, et al. (2012) Heavy metals contamination of a Mediterranean Coastal Ecosystem, Eastern Nile Delta, Egypt. Turkish Journal of Fisheries and Aquatic Sci 12(4): 751-760.

31. Sagheer AA (2004) Geology of coastal area of Wadi Mawr Red Sea, Republic of Yemen. M Sc Thesis Fac Sci Cairo Uni, p. 182.

32. Mahmoud WM (2010) Nutrient salts and some heavy metals in the coastal Red Sea water in front of Hurgada. Ph.D. Thesis, Fac Sci Alexandria Uni, p. 213.

33. Cukrov N, Frančišković-Bilinski S, Hlača B, Barišič D (2011) A recent history of metal accumulation in the sediments of Rijeka harbor, Adriatic Sea, Croatia. Mar Pollut Bull 62(1):154-167.

34. Duman F, Kar M (2012) Temporal variation of metals in water, sediment and tissues of the European Chup (Squalius cephalus). Bull Envi Contam Toxi 89(2): 428-433.

35. Moore JW, Ramamoonthy S (1985) Heavy Metals in Natural Waters Springer-Verlag NY 9: 182-185.

36. Clark R (1992) Marine pollution. Claredon Press, New York: Oxford University, p. 220.

37. Schiff K, Diehl D, Valkirs A (2004) Copper emission from antifouling paint on recreational vessels. Mar Poll Bull 48(3-4): 371-377.

38. Heba H, Al-Mudaffer N (2000) Trace metals in fish, muscles, shrimp and sediment from Red Sea coast of Yemen. Bull. Nat. Inst. Oceanogr Fish ARE 26: 151-165.

39. Al-Edresy M A (2002) Concentration of some heavy metals in KhorKatheb (Al-Hudaydah) area as a result of the sewage effluent impacts, Yemen. M.Sc. Thesis Fac Sci Sana'a Univ, p. 161. 
40. De Carlo E, Spencer K (1995) Records of lead and other heavy metal inputs to sediments of the Ala Wai Canal, O'ahu, Hawaii, Pacific Sci Uni of Hawaii Press 49(4): 471-491.

41. Metwally ME, Al-Muzaini S, Jacob P, Bahloul M, Urushigawa Y, et al (1997) Petroleum hydrocarbons and related heavy metals in the nearshore marine sediments of Kuwait. Envi Int 23(1): 115-121.

42. Al-Abdali F, Massoud A, Al-Ghadban A (1996). Bottom sediments of the Arabian Gulf. Trace metal contents as indicators of pollution and implications for the effect and fate of the Kuwait oil slick. Envi Poll 93(3): 285-301.

43. Patterson C, Settle D, Glover B (1976) Analysis of lead in polluted coastal seawater. Mar Chem 4(4): 305-319.

44. USEPA (1976) Quality criteria for water. Office of Planning and Water, US Environmental Protection Agency, Washington DC. EPA 440(9): 76123.

45. Mansour AM, Nawar A, Madkour H (2011) Metal pollution in marine sediments of selected harbours and industrial areas along the Red Sea coast of Egypt. Ann Naturhist Mus 113: 225-244.

46. Wang M, Qi S, Zhang X (2012) Wetland loss and degradation in the Yellow River Delta, Shandong Province of China. Environ Earth Sci 67(1): 185-188.
47. Hu B, Cui R, Li J, Wei H, Zhao J, et al. (2013) Occurrence and distribution of heavy metals in surface sediments of the Changhua River estuary and adjacent shelf (Hainan Island). Mar Pollut Bull 76(1): 400-405.

48. Chandra A, Rath P, Chandra P, Kumar P, Bramha S (2013) Application of sequential leaching, risk indices and multivariate statistics to evaluate heavy metal contamination of estuarine sediments: Dhamara Estuary, East Coast of India. Environ Monit Assess 185(8): 6719-6737.

49. Gan J, Jia X, Lin Q, Li C, Wang Z, et al. (2000) A primary study on ecological risk caused by the heavy metals in coastal sediments. J Fish China 24: 533-538.

50. Pekey H, Karakas, D, Ayberk S, Tolun L, Bakoğlu M (2004) Ecological risk assessment using trace elements from surface sediments of Izmir Bay (Northeastern Marmara Sea) Turkey. Mar Pollut Bull 48(9-10): 946-953.

51. Singh K, Malik A, Mohan D, Sinha S (2004) Multivariate statistical techniques for the evaluation of spatial and temporal variation in water quality of Gomati River (India)-A case study. Water Res 38(18): 3980-3992.

Your next submission with Juniper Publishers will reach you the below assets

- Quality Editorial service

- Swift Peer Review

- Reprints availability

- E-prints Service

- Manuscript Podcast for convenient understanding

- Global attainment for your research

- Manuscript accessibility in different formats

( Pdf, E-pub, Full Text, Audio)

- Unceasing customer service

Track the below URL for one-step submission

https://juniperpublishers.com/online-submission.php 